\title{
RESEARCH OF EMPLOYEE BENEFITS IN THE OSTRAVA REGION \\ VÝZKUM ZAMĚSTNANECKÝCH VÝHOD NA OSTRAVSKU
}

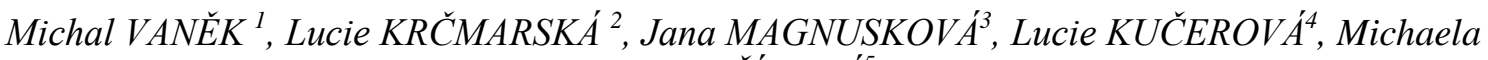 \\ BARTOŠÍKOVÁ \\ ${ }^{1}$ doc. Ing., Institute of Economics and Control Systems, Faculty of Mining and Geology, \\ $V \check{S} B$ - Technical University of Ostrava 17. listopadu 15/2172, Ostrava, tel. (+420) 597323336 \\ e-mail: michal.vanek@vsb.cz \\ ${ }^{2}$ Ing., Institute of Economics and Control Systems, Faculty of Mining and Geology, \\ $V \check{S} B$ - Technical University of Ostrava 17. listopadu 15/2172, Ostrava, tel. (+420) 597324530 \\ e-mail: lucie.krcmarska@vsb.cz \\ ${ }^{3}$ Ing., Institute of Economics and Control Systems, Faculty of Mining and Geology, \\ V̌̌B - Technical University of Ostrava 17. listopadu 15/2172, Ostrava, tel. (+420) 597323375 \\ e-mail: jana.magnuskova@vsb.cz \\ ${ }^{4}$ Ing., Institute of Economics and Control Systems, Faculty of Mining and Geology, \\ $V \check{S} B$ - Technical University of Ostrava 17. listopadu 15/2172, Ostrava , tel. (+420) 597323164 \\ e-mail: lucie.kucerova.st3@vsb.cz \\ ${ }^{5}$ Ing., Institute of Economics and Control Systems, Faculty of Mining and Geology, \\ $V \check{S} B$ - Technical University of Ostrava 17. listopadu 15/2172, Ostrava , tel. (+420) 597324392 \\ e-mail: michaela.sternadelova@vsb.cz
}

\begin{abstract}
The article deals with the issues of employee benefits that influence employee motivation. Thus they participate not only in creating preconditions for company competitiveness, but also in proper running the company and/or return on investments into employees. In relation to the given questions, selected motivation theories and results of some sociological surveys connected with these problems are characterised briefly in the article as well. The focus of the article is the research into employee benefits in the Ostrava region. The authors of the article paid particular attention to the kinds of benefits provided to employees most frequently at present and how these benefits are perceived by employees themselves.
\end{abstract}

Key words: management, motivation, employee benefits, research.

\section{INTRODUCTION}

One of the key tasks of managers is to ensure the required performance of subordinates and colleagues, while the managers and their teams are exposed to constant pressure to improve it. The reason is primarily the pursuit of survival of enterprises in the fierce competitive environment, which usually culminates under conditions of economic recession, or economic crisis. Government and local government authorities generally are not concerned with the survival, but with the adaptation to current budget opportunities of their country or municipalities.

Peter Drucker [3] considers workers as the most valuable capital, and the authors of the article are of the same opinion; therefore this thesis is a paradigm of our article. However, we are aware that many managers do not realize this fact and treat workers completely in an inadequate way.

The performance of employees is affected by three basic components, namely (i) knowledge and skills; (ii) working and organizational conditions, and (iii) motivation. [12] These components not only affect the employee performance, but also influence each other. This article will not deal with all of them, but the attention will focus on motivation. It is interesting that despite the engagement of persons with required knowledge and skills and the creation of adequate working and organizational conditions, the desired performance need not occur due to the lack of adequate employee motivation. 
Employee motivation is one of the major areas of personnel work of managers in each company. Therefore, it is necessary to monitor the development of employee's attitude, opinions and needs and realize that the previously applied methods in the personnel work are no longer the same as before and that they should not be relied upon in the future. Employees should be motivated so that their personal career goals identify with business targets as much as possible. Well-motivated employees are a prerequisite not only for the enterprise competitiveness and the proper functioning of the organization, but also for the return on investments in employees.

Two forces must act at the same time the workers to be motivated. It is the power of needs and the power of incentives (employee benefits).

In the last quarter of 2008, the global financial crisis turned into a global economic recession, which has not spared even the Czech Republic. To survive in the market, businesses were forced to implement a number of measures that did not spare, nor could spare, personnel costs and thus affected employees themselves. The paradox is that employees tend to higher performance for their lower evaluation. First of all, enterprises proceeded to the reduction, or cancellation of employee benefits. Subsequently, the staff costs were decreased by reducing salaries or headcounts.

This is undoubtedly a difficult period for enterprises, managers and employees too. In the most critical moments, it is encouraging if managers can rely on the loyalty of their colleagues and subordinates. It is undisputed that employee benefits affect the employee performance and act on their loyalty to the company as well. Employee benefits can therefore be seen as the most valuable investment an enterprise has, thus into its employees.

The research of the team of authors focused on the employee benefits. The emphasis of our research consisted primarily in identifying the kinds of employee benefits provided by enterprises and how these benefits are perceived by employees themselves. The aim of our article is to familiarize professionals with the findings and conclusions of our research.

\section{MOTIVATION THEORY IN A NUTSHELL}

By studying literature it can be seen that there are many theories of motivation in general. A large number of psychological or other theories of opportunities for motivating and encouraging people to better performance exist. In short, it could be said that each author has his own theory of motivation. Most theories result from the same foundations, and just through the investigation and observations they amend and clarify already known and published theories of motivation.

Many theories try to explain various aspects of the course of motivation. Each of the theory describes a particular problem. Some of them describe the process of motivation; others try to give a guidance how to motivate workers.

The list of motivation theories is quite extensive, so we give a particular attention to the most significant ones.

\subsection{Maslow's Hierarchy of Needs}

The most famous theory of motivation is the hierarchy of needs created by the American psychologist Abraham Maslow. According to Maslow, human needs are arranged in order of priority from the lowest to the highest level. This is the most widespread theory being, however, often dismissed.

The basis of human activity is to satisfy needs. Maslow identified five groups of needs, and put them into the Maslow's pyramid. Once a certain level of needs is satisfied its importance declines and another, a higher level of needs, is acceded. Thus a certain need occurs as soon as all the needs being in the hierarchy before are satisfied.

\subsection{McGregor's X Theory and Y Theory}

The American psychologist McGregor developed another well-known theory, Theory X and Theory Y, representing two extreme views on human relationship to work.

The Theory $\mathrm{X}$ is based on the fact that an average human has an inherent dislike for work and will avoid it if he can. Since the aversion to work is a natural human trait, people need to be forced to work, controlled and directed, and need to be threatened with sanctions in order to exert the required effort to achieve goals. Furthermore, the theory assumes that the average human prefers his activity to be directed in order to avoid responsibility, has little ambition and desires security about everything.

In contrary, the Theory $\mathrm{Y}$ is based on the fact that the expenditure of mental and physical effort in work is as natural as play or rest. Control and punishment are not the only ways to make people exert the desired effort to meet intended goals. People are able to direct themselves and control their activity if they are committed to the 
goals. The level of goal commitment is proportional to the size of their reward. It is also assumed that an average human learns, under proper conditions, not only to accept, but also to seek responsibility. People have a great ability to solve problems using imagination, creativity and ingenuity. The intellectual potentialities of an average human are only partially utilized under the conditions of modern industrial life.

\subsection{Herzberg's Two Factor Theory}

Frederick Herzberg's theory is based on the study of need satisfaction and on motivational effects of this satisfaction. Some job factors result in a high level of motivation and satisfaction, and some factors primarily lead to dissatisfaction of employees.

The purpose of work is in the first place. His conception distinguishes between two factors:

- motivation factors (satisfiers and motivators) - achievement, recognition, independent work, personal growth, responsibility, prospects for promotion, challenging work;

- $\quad$ hygiene factors (dissatisfiers) - work rules, work conditions, relationships with superiors, relationships with colleagues, salary.

\subsection{Vroom's Expectancy Theory}

This theory complements the classical theory of motivational effect with the a priori assessment of attainability of goals.

The expectancy theory can explain the course of a motivation process and the power of motivation for a certain activity. Three conditions must be met the employee to exert efforts:

1. Efforts of employee must lead to a reasonable result.

2. The result of his activity must lead to a reward.

3. The reward must be meaningful to him.

According to the Victor Vroom's theory, the power of motivation can be accurately calculated for a given situation.

Other important motivation theories are:

1. Human Relations Theory (E. Mayo, 1945)

2. Equity Theory (J. P. Adams, 1962)

3. Expectancy Theory (V. H. Vroom, 1964)

4. Achievement Motivation Theory (J. W. Atkinson, 1964)

5. Goal Setting Theory (E. Locke, 1967)

6. Theory of Needs (D. McClelland, 1976)

7. Theory of Intrinsic Motivation (G. Wiswede, 1980)

\section{MOTIVATION OF EMPLOYEES AT PRESENT}

Generally speaking, the purpose of motivation is not different today compared to previous decades or centuries. To motivate employees means to create their intrinsic interest, willingness and desire to engage in fulfilling their tasks. The motivation of workmates is realized by a manager through creating, developing and implementing the inducements for desirable behaviour which we call motives or incentives. The difference can be seen just in the specific tools and techniques applied by managers in an enterprise.

Apart from the positive and negative motivation, we encounter:

- Intangible motivation focusing on:

○ Interest in work

- Achieved performance results and related success (praise $\mathrm{x}$ criticism)

- Positive interpersonal relationships with superiors and other employees

- Rate of stress and anxiety (balanced). The lack of stress leads to routine, excessive stress leads to mental exhaustion.

- Tangible motivation includs:

- Mobile phones

- Company car

- Superior health care

○ Company products 


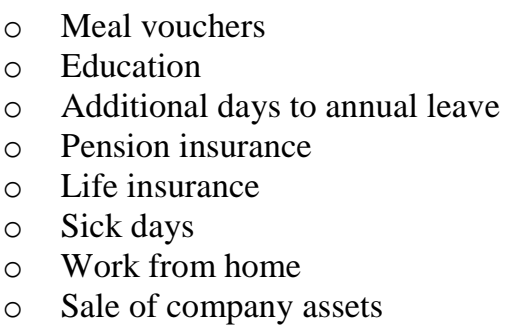

- Anniversary rewards

- Transport to work

$\circ$ Additional payment of disease

Flexible benefits

Extra compensation

Loans

Accommodation

Other employee benefits can include, for example, time off for arranging personal matters - free days, corporate nursery, babysitting.

Benefits are very popular among employees and become an increasingly important tool for personnel policy. They are used for example to prevent employee burnout, when passion and enthusiasm of an employee gradually passes into the stage of full exhaustion. According to human resources specialists, if the first signs of burnout are found out, the best thing you can do is to achieve work-life balance, e.g. by sport and cultural activities and holidays.

According to human resources specialists, the most effective way to increase motivation are just recreational benefits such as holiday allowance and contributions for sport and cultural activities. These benefits sound attractive to $91 \%$ of employees and therefore become a frequent basis of cafeteria.

Another effective tool is a car for private purposes. Favourites are also gift vouchers.

Although we can encounter a series of benefits, it turns out that despite many reservations about money as a motivational factor, money remains an essential tool for stimulating efforts. The motivation by money can have a variety of forms. This may be a basic salary, which gives employees security, but it does not stimulate much further efforts. It may also be a reward depending on the achievement of set goals such as profit amount. Another form of monetary compensation can be employee shares, stock options, etc. [7]

Although the use of various forms of employee motivation based on financial rewards is a widespread phenomenon, it has its natural limits of efficiency. Generally, from a certain point the increase in financial rewards gradually loses its effectiveness and does not motivate enough to further effort and initiatives in favour of the company. Marginal utility of additional money is less than the utility of lost time or than the value of effort. Employees, who ensured a high level of earnings and accumulated enough personal wealth, will not respond to a further increase of financial rewards in an adequate way for the firm. In case of such employees, other forms of motivation must then take place with regard to their social status, especially the confirmation of their role in the company. They do not consider their professional activities as a source of livelihood, but rather as the realization of their talent, realization of their personality, the source of recognition and positive emotions. These values cannot be substituted by any sum of money. [7]

\section{RESEARCH OF EMPLOYEE BENEFITS}

The issues of employee motivation and mainly employee benefits are often a subject of sociological research. For example, according to the HR consulting firm Hay Group and its latest survey, $31 \%$ of companies in the country cut into benefits. The benefit cutbacks affected mostly top management and manual employees. These were especially the benefits associated with insurance (pension, capital, life and disability insurance). Education without the employee contribution was reviewed as well. [9]

However, from the point of view of an employee just insurance is still of great importance and this benefit further strengthen its importance with the expected pension system reform. Conversely, some benefits are gradually dying out. According to the data of the Mercer Company these are mainly bonuses for anniversary of birth, birth of child, weddings and anniversary of employment.

The Salary \& Benefits Guide 2009-2010 from the international company Robert Half 1 also showed that the area of employee benefits was significantly affected in 2009 by the unfavourable economic situation. The

\footnotetext{
${ }^{1}$ The study Salary \& Benefits Study Guide 2009-2010 contains the summary information about employee benefits and average gross salaries provided to professionals in finance and accounting, sales and marketing, IT and telecommunications, human resources, logistics, customer service, managerial support and justice. The research was conducted from 14 September to 6 December 2009 and it was attended by more than 1450 respondents in total. The main source of information was a survey of salaries and benefits among the candidates, interviews with the candidates and the information from clients of Robert Half International. The annual survey is the fifth in a row and illustrates the current situation on the labour market in Prague and its surroundings.
} 
results of the study show that companies cut in benefits across the board in all tracked fields. They were removed in about 25 to $40 \%$ of cases, most notably for financial and accounting positions. The most common removed benefits involved language courses and 13 salaries. [11]

The research also showed that the employee benefits ceased to be crucial in deciding on job positions. The most important criterion was the company stability and opportunities for professional growth. [11]

The research also showed that employees require extra additional week to annual leave. The most common benefits on a long-term basis are meal vouchers, five weeks' annual leave and refreshments. Many companies provide their employees a business laptop and mobile phone.

\subsection{Research of employee benefits in the Ostrava Region}

This theory complements the classical theory.

The research of employee benefits was conducted by the authors' team as well. Two team members had dealt with the issues of motivation and motivational factors earlier in their research work. The findings were published in the journal $\mathbf{2}$ and conferences.

The previous research work was followed by a sociological survey aiming at the evaluation of selected motivational elements - employee benefits in the Ostrava Region. The results are presented below.

The actual research was carried out in the months of October and November 2010. At the beginning of the research work the authors formulated the following hypotheses:

1. More than $60 \%$ of employees prefer tangible motivation to intangible motivation.

2. More than $60 \%$ of managers prefer intangible motivation to tangible motivation.

3. More than $70 \%$ of ordinary employees attribute the importance greater than 7 to free days (Sick Days, Free Days).

4. More than $60 \%$ of employees over 40 years of age attribute the importance greater than 7 to pension insurance.

5. More than $60 \%$ of employees over 50 years of age attribute the importance greater than 7 to free days (sick days, free days).

6. More than $70 \%$ of employees attribute the importance greater than 7 to the 13 th and 14 salaries.

7. More than $60 \%$ of employees younger than 41 years attribute the importance greater than 7 to corporate nurseries.

8. More than $60 \%$ of employers have not implemented the cafeteria system so far.

9. More than $60 \%$ of employees younger than 41 years attribute the importance greater than 7 to contributions for cultural and sport events.

10. More than $70 \%$ of employees attribute the importance less than 4 to the bonuses for anniversaries of birth and anniversaries of employment.

11. More than $70 \%$ of managers are looking forward to work.

The research was conducted through a questionnaire survey. The questionnaire consisted of 11 questions; the first 5 questions examined the respondent's demographic profile. Except for the last three essentially unstructured questions that the interviewees answered only positive responds, it consisted of scale questions.

The research examined workers in an employment or similar relationship living in the Ostrava Region.

With regard to limited financial means, we obtain the empirical data through non-probability sampling. We created an opportunity set so that we used mainly the students of the Faculty of Mining and Geology, VSB TU Ostrava. We directly addressed combined studies students (200 respondents) who completed the questionnaire themselves; and we also addressed the parents of full-time students (200 respondents).

Thus we contacted 400 respondents in total, however all questionnaires were not returned to be evaluated. The smallest return of questionnaires was on the part of the full-time students, or their parents. Thus we evaluated a total of 219 questionnaires, representing a return of $54.75 \%$.

The evaluation showed that most of our respondents were males $(55.25 \%)$. The most represented was the age group 31-40 (31.96\%), followed by the age group 41-50 and the age group 20-30 (25.57\%). The least represented is the age group 61 and over $(1.83 \%)$ and the age group $51-60(10.05 \%)$.

\footnotetext{
${ }^{2}$ VANĚK, Michal; MAGNUSKOVÁ, Jana; TYKAL, Martin. Motivace pracovníků cesta k úspěchu. Ekonomická revue VŠB - TU Ostrava, Ekonomická fakulta, 2006, roč. 9, č. 1., s. 15-25.

VANĚK, Michal; MAGNUSKOVÁ, Jana. Motivace pracovníků cesta k úspěchu. 2. část. Ekonomická revue VŠB - TU Ostrava, Ekonomická fakulta, 2006, roč. 9, č. 2., s. 70-79.
} 
In terms of education, the largest was the group of respondents with secondary education - 38\% (elementary education $-1.37 \%$, apprenticeship without GCE $-20.55 \%$, higher vocational education $-4.57 \%$ and university education $35.62 \%$ ).

Ordinary employees $(75.80 \%)$ prevailed among our respondents; there were $24.20 \%$ managers among them. The respondents worked mainly in the private sector $(65.30 \%)$, the remaining $34.70 \%$ were employed in the public sector.

The focus of our sociological research consisted in investigating the perception of motivational factors and benefits. The results, which are presented in the following graphs and comments, were examined in terms of the age and educational3 structure of the respondents in more detail. The effect of employment status on the subject of our research was studied as well.

The first research question examined how employees are happy at work. Their satisfaction or dissatisfaction was expressed by the respondents on a scale of 10 evaluation points; the lowest satisfaction was represented by a value of 1 .

Our investigation showed that the respondents most often chose a value of 5, namely in a total of $23.74 \%$. The second highest choice was $8(17.18 \%)$ and the third option was a value of $7(15.98 \%)$. The evaluation results of job satisfaction with regard to the education level, age and job position are given in graphs 1 to 3 .

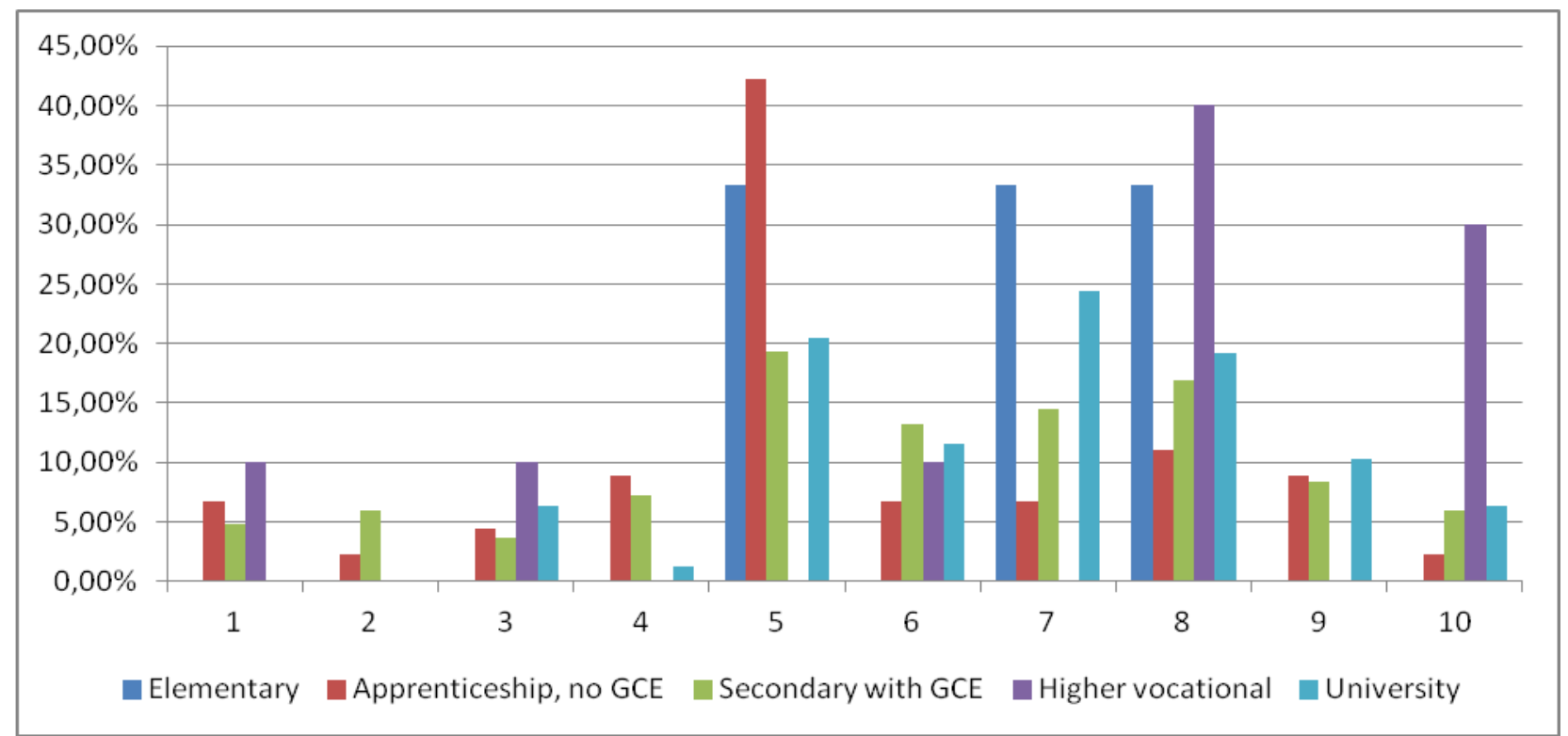

Fig. 1 Satisfaction in employment by attained education Source: Inherent processing

\footnotetext{
${ }^{3}$ Given that elementary education has three respondents only, they are involved in the results for completeness.
} 


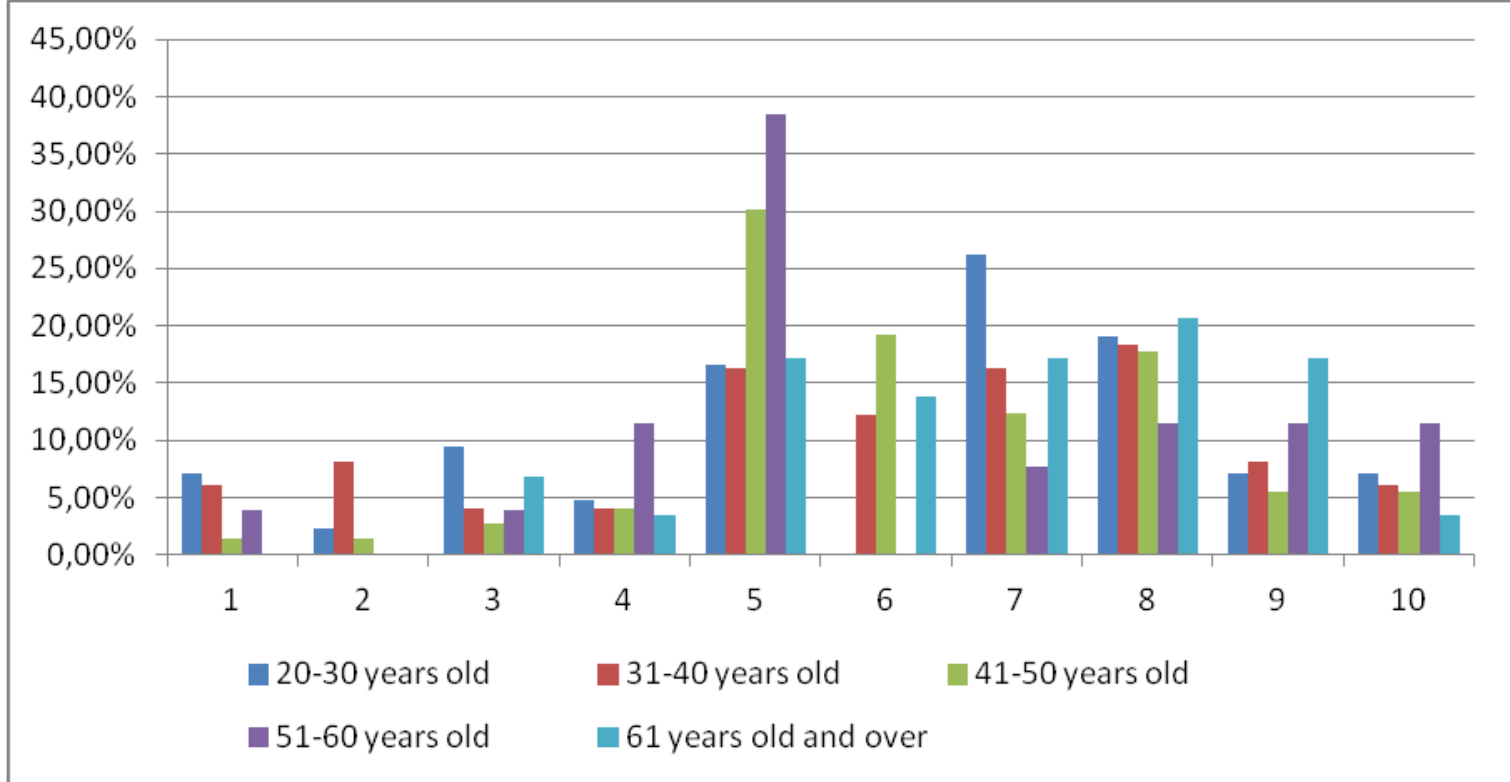

Fig. 2 Satisfaction in employment by age of respondents Source: Inherent processing

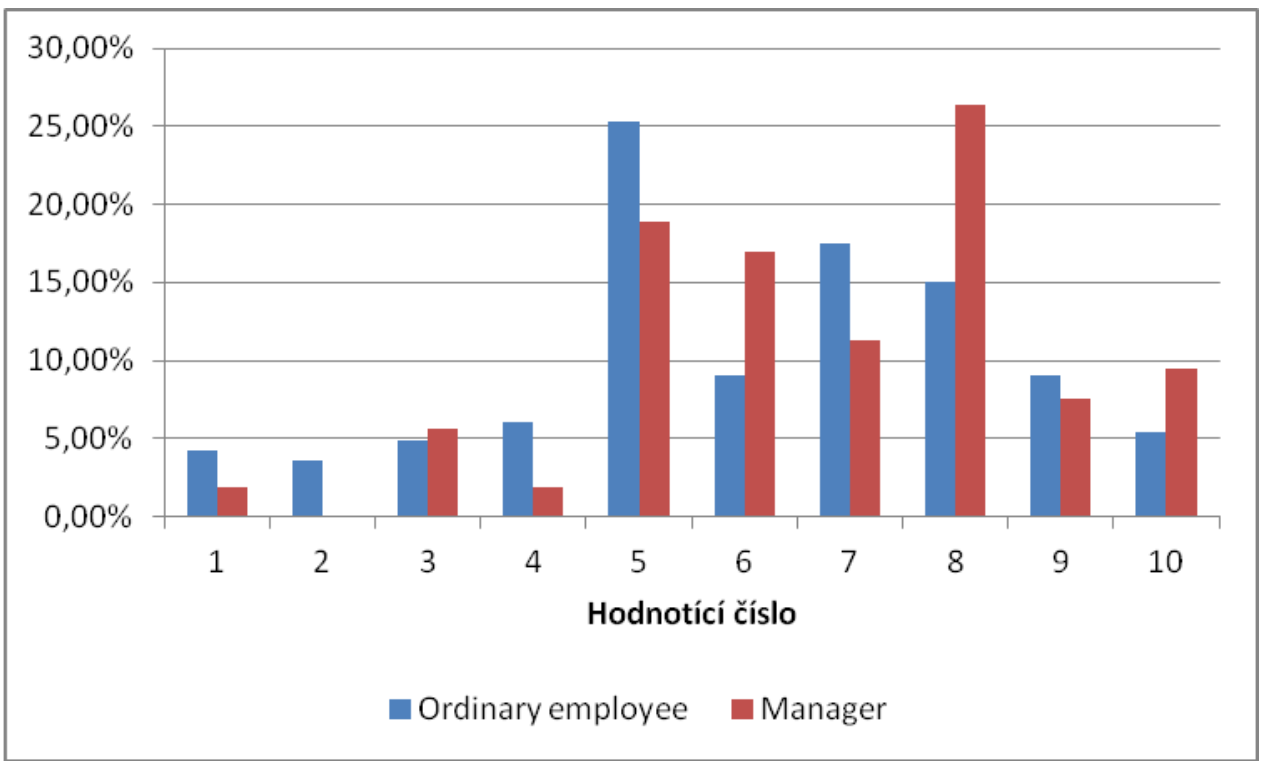

Fig. 3 Satisfaction in employment by job title Source: Inherent processing

It is apparent from the graphs that education and age are not crucial for job satisfaction. A slight shift to a higher level of job satisfaction can be observed in case of managers. While the ordinary employees preferred mostly a value of $5(25.30 \%), 26.42 \%$ of managers chose a value of 8 . A value of 5 was preferred by $18.87 \%$ of managers.

Further the importance of tangible and intangible forms of motivation for the performance and satisfaction of employees was examined. If we perceive our respondents as a homogenous group, then it can be seen from the graph 4 that $52.05 \%$ of respondents prefer tangible motivation. The same importance of tangible and intangible forms of motivation is indicated by $42.92 \%$ of respondents. 


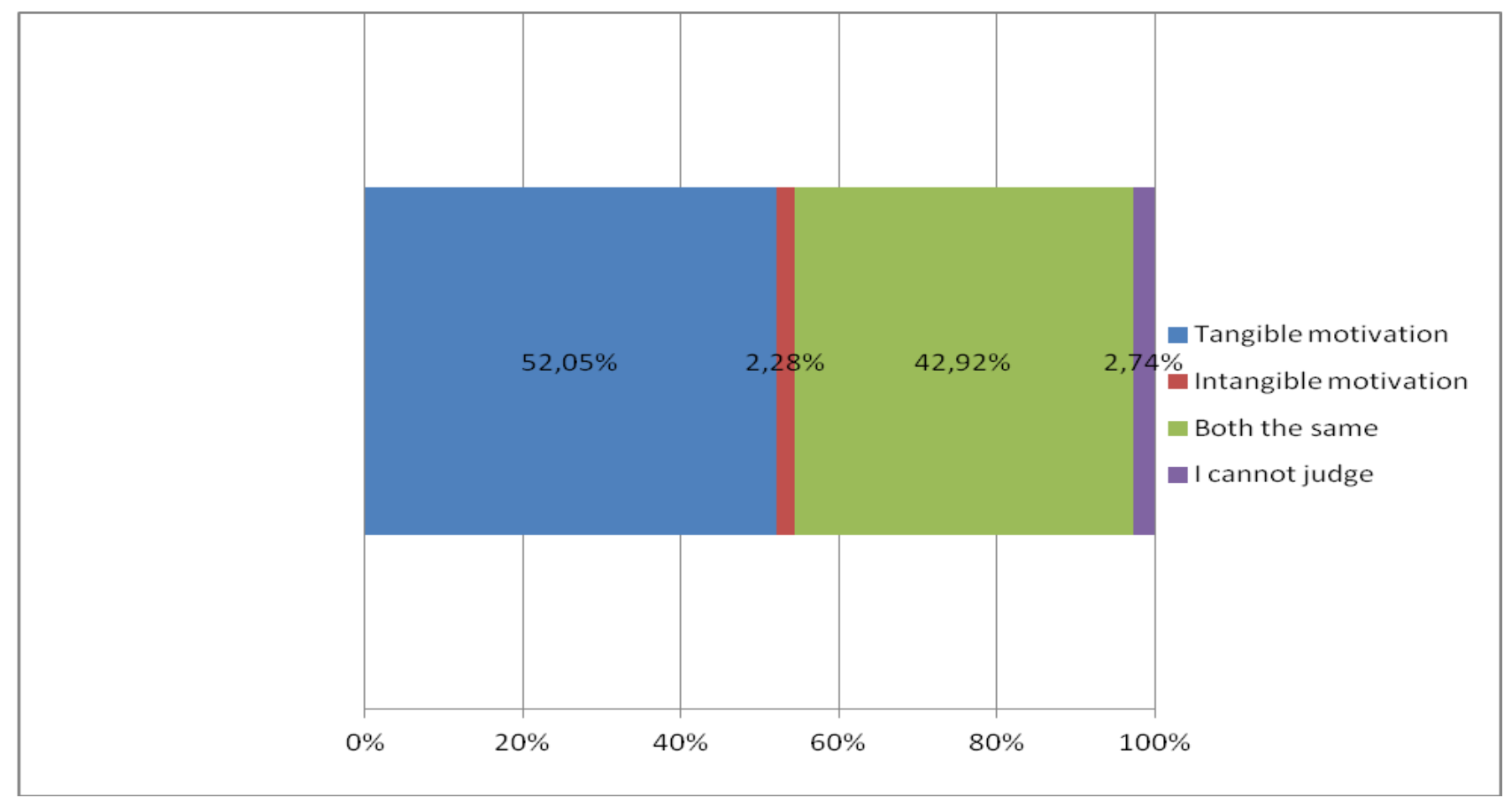

Fig. 4: Importance of tangible and intangible forms of motivation Source: Inherent processing

Table 1 shows how the educational groups are represented in different parts of our pie chart. However, let us bear in mind in the interpretation that the size of the representation of an educational group reflects the number of respondents with the certain level of education.

Tab. 1 Representation of educational groups in terms of the importance of tangible and intangible forms of motivation

\begin{tabular}{|c|c|c|c|c|c|c|}
\hline Variants & $\begin{array}{l}\text { Elementary } \\
\text { education }\end{array}$ & $\begin{array}{l}\text { Apprenticeship } \\
\text { without GCE }\end{array}$ & $\begin{array}{l}\text { Secondary } \\
\text { education } \\
\text { with GCE }\end{array}$ & $\begin{array}{l}\text { Higher } \\
\text { vocational } \\
\text { education }\end{array}$ & $\begin{array}{l}\text { University } \\
\text { education }\end{array}$ & Total \\
\hline $\begin{array}{l}\text { Percentage } \\
\text { respondents }\end{array}$ & $1.37 \%$ & $20.55 \%$ & $37.90 \%$ & $4.57 \%$ & $35.62 \%$ & $100.00 \%$ \\
\hline Tangible motivation & $0.46 \%$ & $12.33 \%$ & $19.63 \%$ & $1.37 \%$ & $18.26 \%$ & $52.05 \%$ \\
\hline Intangible motivation & $0.00 \%$ & $0.00 \%$ & $0.91 \%$ & $0.00 \%$ & $1.37 \%$ & $2.28 \%$ \\
\hline Both the same & $0.91 \%$ & $7.76 \%$ & $16.44 \%$ & $2.74 \%$ & $15.07 \%$ & $42.92 \%$ \\
\hline I cannot judge & $0.00 \%$ & $0.46 \%$ & $0.91 \%$ & $0.46 \%$ & $0.91 \%$ & $2.74 \%$ \\
\hline
\end{tabular}

Source: Inherent processing

Table 2 presents how the respondents perceive forms of motivation with regard to attained education.

Tab. 2 Importance of motivation in each educational group

\begin{tabular}{|c|c|c|c|c|c|}
\hline Variants & $\begin{array}{l}\text { Elementary } \\
\text { education }\end{array}$ & $\begin{array}{l}\text { Apprenticeshi } \\
\mathrm{p} \text { without } \\
\text { GCE }\end{array}$ & $\begin{array}{l}\text { Secondary } \\
\text { education } \\
\text { with GCE }\end{array}$ & $\begin{array}{l}\text { Higher } \\
\text { vocational } \\
\text { education }\end{array}$ & $\begin{array}{l}\text { University } \\
\text { education }\end{array}$ \\
\hline Tangible motivation & $33.33 \%$ & $60.00 \%$ & $51.81 \%$ & $30.00 \%$ & $51.28 \%$ \\
\hline $\begin{array}{l}\text { Intangible } \\
\text { motivation }\end{array}$ & $0.00 \%$ & $0.00 \%$ & $2.41 \%$ & $0.00 \%$ & $3.85 \%$ \\
\hline Both the same & $66.67 \%$ & $37.78 \%$ & $43.37 \%$ & $60.00 \%$ & $42.31 \%$ \\
\hline I cannot judge & $0.00 \%$ & $2.22 \%$ & $2.41 \%$ & $10.00 \%$ & $2.56 \%$ \\
\hline
\end{tabular}

Source: Inherent processing 
Tangible motivation is of the greatest importance for the respondents with apprenticeship without GCE $(60.00 \%)$ and the respondents with secondary education with GCE (51.81\%). A surprising fact is that even the respondents with university education preferred tangible motivation (51.28\%). Intangible motivation is perceived marginally by different educational groups. The same importance is given to tangible and intangible forms of motivation by $60 \%$ of respondents with higher vocational education. Almost identical it is then perceived by the respondents with secondary education with GCE (43.37\%) and university graduates (42.31\%).

Analogously, let us examine the effect of age of the respondents on their preferences in relation to tangible and intangible forms of motivation. Table 3 shows the representation of age groups in the perception of the importance of motivational forms.

Tab. 3 Representation of age groups in terms of the importance of tangible and intangible forms of motivation

\begin{tabular}{|c|c|c|c|c|c|c|}
\hline Variants & $20-30$ & $31-40$ & $41-50$ & $51-60$ & 61 and over & Total \\
\hline $\begin{array}{l}\text { Percentage } \\
\text { respondents }\end{array}$ & $25.57 \%$ & $31.96 \%$ & $30.59 \%$ & $10.05 \%$ & $1.83 \%$ & $100.00 \%$ \\
\hline Tangible motivation & $11.42 \%$ & $16.89 \%$ & $18.26 \%$ & $4.57 \%$ & $0.91 \%$ & $52.05 \%$ \\
\hline Intangible motivation & $0.91 \%$ & $0.46 \%$ & $0.91 \%$ & $0.00 \%$ & $0.00 \%$ & $2.28 \%$ \\
\hline Both the same & $12.33 \%$ & $13.70 \%$ & $10.50 \%$ & $5.48 \%$ & $0.91 \%$ & $42.92 \%$ \\
\hline I cannot judge & $0.91 \%$ & $0.91 \%$ & $0.91 \%$ & $0.00 \%$ & $0.00 \%$ & $2.74 \%$ \\
\hline
\end{tabular}

Source: Inherent processing

The following Table 4 shows the importance of forms of motivation for different age groups.

Tangible motivation is preferred by the age groups $41-50(59.70 \%), 31-40(52.86 \%)$ and by $50 \%$ of the respondents older than 61 years. Intangible motivation was more important for the age groups 20-30 (3.57\%) and 41-50 (2.99\%). The same importance of both tangible and intangible forms of motivation was given by $54.55 \%$ of the employees aged 51-60; 50.00\% of the respondents older than 61 years; and $48.21 \%$ of the respondents in the age group 20-30.

Tab. 4 Importance of motivation in selected age groups

\begin{tabular}{llllll}
\hline \multicolumn{1}{c}{ Variants } & $20-30$ & $31-40$ & $41-50$ & $51-60$ & 61 and over \\
\hline $\begin{array}{l}\text { Tangible } \\
\text { motivation }\end{array}$ & $44.64 \%$ & $52.86 \%$ & $59.70 \%$ & $45.45 \%$ & $50.00 \%$ \\
$\begin{array}{l}\text { Intangible } \\
\text { motivation }\end{array}$ & $3.57 \%$ & $1.43 \%$ & $2.99 \%$ & $0.00 \%$ & $0.00 \%$ \\
$\begin{array}{l}\text { Both the same } \\
\text { I cannot judge }\end{array}$ & $48.21 \%$ & $42.86 \%$ & $34.33 \%$ & $54.55 \%$ & $50.00 \%$ \\
\hline
\end{tabular}

Source: Inherent processing

The last evaluation criterion for assessing the importance of motivation was a job position. Two basic positions were considered, in particular the position of an ordinary employee and a managerial post. The importance of the considered forms of motivation for employees by their position is indicated in the graph in Fig. 5. 


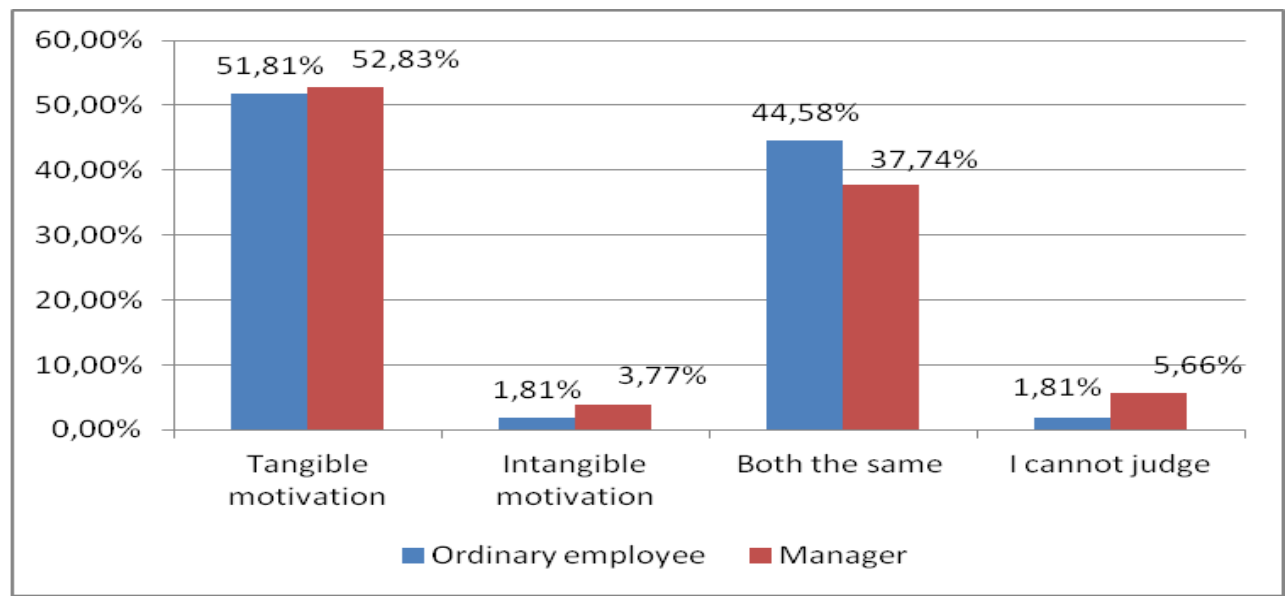

Fig. 5 Importance of motivational forms by position

Source: Inherent processing

The graph shows that even the job position does not change the importance of motivational forms too much, as both ordinary employees and managers prefer tangible motivation as a dominant form. It was confirmed by $51.81 \%$ of ordinary employees and $52.83 \%$ of managers. Intangible motivation is important for 3.77 of employees in managerial positions. It is interesting that $5.66 \%$ of managers are not able to assess the importance of motivational forms.

Our investigation showed that the tangible form of motivation is a crucial form for motivating employees. The cause we see especially in the fact that the average salary is not achieved by around two thirds of Czechs on a long-term basis.

The focus of our research we see in determining the way in which the individual employee benefits are assessed by employees. Similarly as in the assessment of employee satisfaction at work, the respondents could choose from a variety of evaluation points from 1 to 10 in their benefit assessment, where the highest evaluation value corresponded to a value of 10 . The overall importance of these employee benefits resulted from an evaluation number. The evaluation number is given by:

$$
H \check{\mathbf{c}}=\sum_{i=1}^{10} n_{i} \cdot i
$$

where:

EN (HČ) - evaluation number

$\mathrm{n}$ - number of preferences of an evaluation point

i - scale of evaluation points $(1-10)$

The following graphs 6-9 show the importance of employee benefits for individual interest groups (education, age, job position of employees).

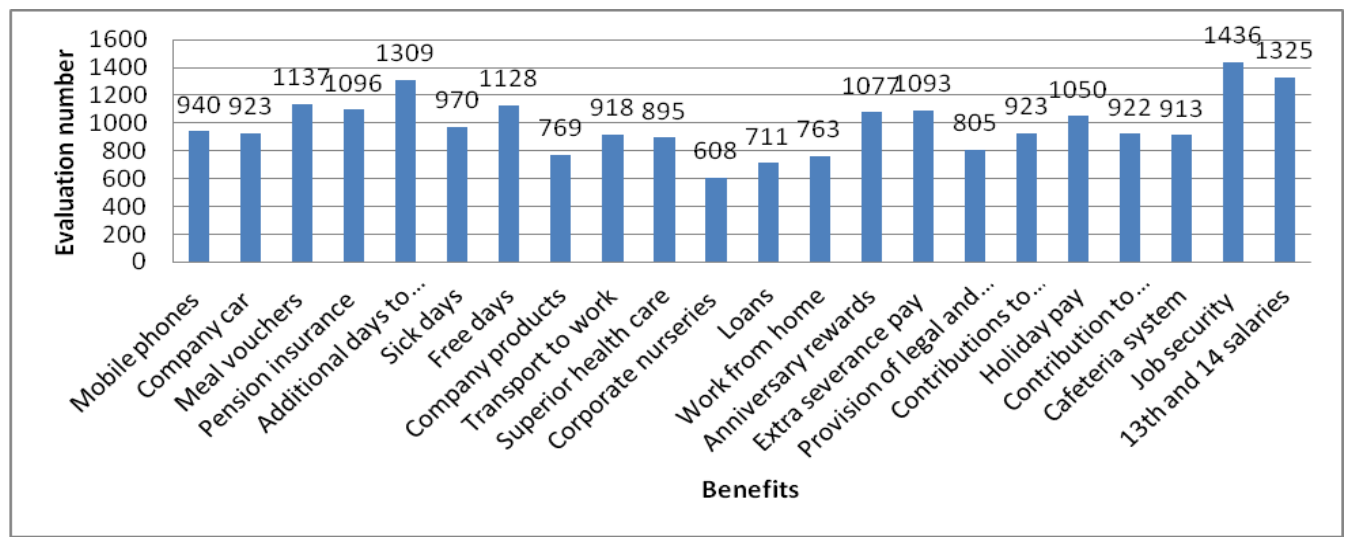

Fig. 6 Comparison of employee benefits by interest groups Source: Inherent processing 
The employee benefits include job security. This is not a pure employment benefit; however there is no doubt that job security affects the performance of employees. The respondents attached the greatest importance just to it. Even in a more detailed analysis (Tables 5 - 7) job security is the dominant factor affecting employees in different age and educational groups of ordinary employees and managers.

Tab. 5 Importance of employee benefits by education

\begin{tabular}{|c|c|c|c|c|c|}
\hline & $\begin{array}{r}\text { Elementary } \\
\text { education }\end{array}$ & $\begin{array}{l}\text { Apprenticeship } \\
\text { without GCE }\end{array}$ & $\begin{array}{r}\text { Secondary } \\
\text { education } \\
\text { with GCE }\end{array}$ & $\begin{array}{r}\text { Higher } \\
\text { vocational } \\
\text { education }\end{array}$ & $\begin{array}{r}\text { University } \\
\text { education }\end{array}$ \\
\hline Mobile phone & $0.50 \%$ & $4.01 \%$ & $3.90 \%$ & $4.16 \%$ & $5.10 \%$ \\
\hline Company car & $0.75 \%$ & $3.24 \%$ & $3.88 \%$ & $3.57 \%$ & $5.26 \%$ \\
\hline Meal vouchers & $6.02 \%$ & $4.32 \%$ & $5.35 \%$ & $4.67 \%$ & $5.64 \%$ \\
\hline Pension insurance & $5.01 \%$ & $5.17 \%$ & $4.98 \%$ & $5.52 \%$ & $4.99 \%$ \\
\hline Additional days to annual leave & $6.52 \%$ & $5.86 \%$ & $6.15 \%$ & $7.47 \%$ & $5.78 \%$ \\
\hline Sick days & $3.76 \%$ & $4.44 \%$ & $4.51 \%$ & $5.43 \%$ & $4.34 \%$ \\
\hline Free days & $5.51 \%$ & $5.31 \%$ & $4.89 \%$ & $5.09 \%$ & $5.43 \%$ \\
\hline Company products & $2.76 \%$ & $3.51 \%$ & $4.27 \%$ & $2.72 \%$ & $3.04 \%$ \\
\hline Transport to work & $2.26 \%$ & $4.40 \%$ & $4.59 \%$ & $3.23 \%$ & $4.05 \%$ \\
\hline Superior health care & $2.76 \%$ & $4.44 \%$ & $4.38 \%$ & $5.01 \%$ & $3.66 \%$ \\
\hline Corporate nurseries & $3.76 \%$ & $2.04 \%$ & $3.14 \%$ & $2.21 \%$ & $2.91 \%$ \\
\hline Loans & $2.76 \%$ & $2.74 \%$ & $3.64 \%$ & $3.74 \%$ & $3.17 \%$ \\
\hline Work from home & $5.01 \%$ & $2.02 \%$ & $3.73 \%$ & $1.87 \%$ & $4.23 \%$ \\
\hline Anniversary rewards & $5.01 \%$ & $5.43 \%$ & $4.93 \%$ & $3.90 \%$ & $4.91 \%$ \\
\hline Extra severance pay & $5.01 \%$ & $5.79 \%$ & $4.67 \%$ & $4.92 \%$ & $5.01 \%$ \\
\hline $\begin{array}{l}\text { Provision of legal and } \\
\text { psychological consultations }\end{array}$ & $6.52 \%$ & $4.13 \%$ & $3.80 \%$ & $3.40 \%$ & $3.32 \%$ \\
\hline $\begin{array}{l}\text { Contributions to cultural and } \\
\text { sport events }\end{array}$ & $7.27 \%$ & $5.14 \%$ & $4.14 \%$ & $5.09 \%$ & $3.65 \%$ \\
\hline Holiday pay & $7.02 \%$ & $5.36 \%$ & $4.46 \%$ & $5.43 \%$ & $4.74 \%$ \\
\hline Contribution to drinking regime & $4.51 \%$ & $4.78 \%$ & $4.15 \%$ & $4.24 \%$ & $4.06 \%$ \\
\hline Cafeteria system & $7.27 \%$ & $4.23 \%$ & $4.35 \%$ & $3.82 \%$ & $3.98 \%$ \\
\hline Job security & $5.01 \%$ & $7.06 \%$ & $6.44 \%$ & $7.22 \%$ & $6.55 \%$ \\
\hline 13th and 14 salaries & $5.01 \%$ & $6.56 \%$ & $5.63 \%$ & $7.30 \%$ & $6.20 \%$ \\
\hline
\end{tabular}

Source: Inherent processing 
Tab. 6 Importance of employee benefits by respondents' age

\begin{tabular}{|c|c|c|c|c|c|}
\hline & $20-30$ & $31-40$ & $41-50$ & $51-60$ & 61 and over \\
\hline Mobile phone & $4.99 \%$ & $4.75 \%$ & $3.63 \%$ & $3.36 \%$ & $5.22 \%$ \\
\hline Company car & $4.41 \%$ & $4.85 \%$ & $3.78 \%$ & $3.36 \%$ & $3.21 \%$ \\
\hline Meal vouchers & $5.58 \%$ & $5.35 \%$ & $4.74 \%$ & $5.31 \%$ & $7.03 \%$ \\
\hline Pension insurance & $4.27 \%$ & $4.74 \%$ & $5.34 \%$ & $6.91 \%$ & $7.43 \%$ \\
\hline $\begin{array}{l}\text { Additional days to } \\
\text { annual leave }\end{array}$ & $6.06 \%$ & $5.79 \%$ & $6.22 \%$ & $6.14 \%$ & $5.42 \%$ \\
\hline Sick days & $4.63 \%$ & $4.77 \%$ & $4.51 \%$ & $3.13 \%$ & $2.81 \%$ \\
\hline Free days & $5.04 \%$ & $5.39 \%$ & $5.07 \%$ & $4.78 \%$ & $8.03 \%$ \\
\hline Company products & $4.06 \%$ & $3.41 \%$ & $3.51 \%$ & $3.19 \%$ & $0.80 \%$ \\
\hline Transport to work & $4.47 \%$ & $4.46 \%$ & $3.90 \%$ & $4.49 \%$ & $2.61 \%$ \\
\hline Superior health care & $3.50 \%$ & $4.36 \%$ & $4.38 \%$ & $4.25 \%$ & $4.22 \%$ \\
\hline Corporate nurseries & $3.06 \%$ & $3.16 \%$ & $2.24 \%$ & $2.83 \%$ & $3.61 \%$ \\
\hline Loans & $3.53 \%$ & $3.08 \%$ & $3.39 \%$ & $2.07 \%$ & $5.02 \%$ \\
\hline Work from home & $3.69 \%$ & $4.28 \%$ & $3.16 \%$ & $2.18 \%$ & $1.81 \%$ \\
\hline Anniversary rewards & $4.68 \%$ & $5.01 \%$ & $5.18 \%$ & $4.84 \%$ & $4.82 \%$ \\
\hline Extra severance pay & $4.75 \%$ & $5.11 \%$ & $5.06 \%$ & $5.84 \%$ & $4.42 \%$ \\
\hline $\begin{array}{l}\text { Provision of legal and } \\
\text { psychological } \\
\text { consultations }\end{array}$ & $3.40 \%$ & $3.34 \%$ & $4.14 \%$ & $4.37 \%$ & $3.21 \%$ \\
\hline $\begin{array}{l}\text { Contributions to cultural } \\
\text { and sport events }\end{array}$ & $4.35 \%$ & $3.54 \%$ & $4.59 \%$ & $4.84 \%$ & $4.82 \%$ \\
\hline Holiday pay & $4.78 \%$ & $4.35 \%$ & $5.37 \%$ & $4.43 \%$ & $5.02 \%$ \\
\hline $\begin{array}{l}\text { Contribution to drinking } \\
\text { regime }\end{array}$ & $4.49 \%$ & $3.80 \%$ & $4.37 \%$ & $4.78 \%$ & $3.41 \%$ \\
\hline Cafeteria system & $4.15 \%$ & $3.86 \%$ & $4.61 \%$ & $4.07 \%$ & $3.61 \%$ \\
\hline Job security & $6.42 \%$ & $6.72 \%$ & $6.56 \%$ & $6.97 \%$ & $7.43 \%$ \\
\hline 13th and 14 salaries & $5.69 \%$ & $5.87 \%$ & $6.24 \%$ & $7.85 \%$ & $6.02 \%$ \\
\hline
\end{tabular}

Source: Inherent processing 
Tab. 7 Importance of employee benefits by position

\begin{tabular}{|c|c|c|}
\hline & $\begin{array}{l}\text { Ordinary } \\
\text { employee }\end{array}$ & Manager \\
\hline Mobile phone & $4.33 \%$ & $5.12 \%$ \\
\hline Company car & $4.21 \%$ & $5.65 \%$ \\
\hline Meal vouchers & $5.24 \%$ & $4.85 \%$ \\
\hline Pension insurance & $5.05 \%$ & $5.28 \%$ \\
\hline Additional days to annual leave & $6.03 \%$ & $6.20 \%$ \\
\hline Sick days & $4.47 \%$ & $4.32 \%$ \\
\hline Free days & $5.20 \%$ & $4.49 \%$ \\
\hline Company products & $3.54 \%$ & $3.74 \%$ \\
\hline Transport to work & $4.23 \%$ & $4.03 \%$ \\
\hline Superior health care & $4.12 \%$ & $4.16 \%$ \\
\hline Corporate nurseries & $2.80 \%$ & $2.88 \%$ \\
\hline Loans & $3.28 \%$ & $3.39 \%$ \\
\hline Work from home & $3.52 \%$ & $3.70 \%$ \\
\hline Anniversary rewards & $4.96 \%$ & $4.40 \%$ \\
\hline Extra severance pay & $5.04 \%$ & $4.39 \%$ \\
\hline $\begin{array}{l}\text { Provision of legal and psychological } \\
\text { consultations }\end{array}$ & $3.71 \%$ & $3.36 \%$ \\
\hline Contributions to cultural and sport events & $4.25 \%$ & $3.86 \%$ \\
\hline Holiday pay & $4.84 \%$ & $5.11 \%$ \\
\hline Contribution to drinking regime & $4.25 \%$ & $3.99 \%$ \\
\hline Cafeteria system & $4.21 \%$ & $4.13 \%$ \\
\hline Job security & $6.62 \%$ & $6.61 \%$ \\
\hline Payment of 13th and 14 salaries & $6.11 \%$ & $6.34 \%$ \\
\hline
\end{tabular}

Source: Inherent processing

As the value of the evaluation number is affected by numbers of members of the evaluated groups of employees, the results are presented in a relative expression.

Aside from the job security, the payment of the 13th and 14 salaries and additional days to annual leave are strongly preferred by employees to other benefits. Free days, meal vouchers and pension insurance, anniversary rewards and extra severance pay are also interesting for employees.

The tendency towards these benefits undoubtedly relates to the fact that employees prefer tangible forms of motivation regardless of education, age or position. Therefore, the above benefits are also important for employees in a more detailed analysis, as illustrated by Tables 5 to 7 .

The fact that only $45 \%$ of employers offer benefits in the form of cafeteria may also be considered an interesting finding.

\section{HYPOTHESES TESTING}

To be able to competently assess the hypotheses defined at the beginning of our research, it is necessary to expose them to a test. In order to adopt or reject our hypotheses, we applied the relative frequency test.

In general, we worked with the following null hypothesis [4]

$\mathrm{H} 0>\pi=\pi 0$.

The alternative hypothesis was considered as follows:

$\mathrm{H} 1: \pi>\pi 0$ 
We used the following statistics as test criterion: [4]

$$
U=\frac{p-\pi_{0}}{\sqrt{\frac{\pi_{0\left(1-\pi_{0}\right)}}{n}}}
$$

The mentioned test criterion has, at the validity of $\mathrm{H} 0$, an asymptotic standard normal distribution, where $p$ is the selective relative frequency. [3] A usual level of significance, $\alpha=0.05$ was chosen. For the alternative hypothesis, the critical range is defined as follows:

$$
\mathrm{U} \geq 1,645 \text {. }
$$

The results of the hypotheses tests are shown in Table 8.

Tab. 8 Hypotheses testing

\begin{tabular}{|c|c|c|c|c|c|}
\hline Tested hypothesis & 7 & 8 & 9 & 10 & 11 \\
\hline Total respondents & 126 & 219 & 126 & 219 & 53 \\
\hline Total matching & 26 & 99 & 30 & 86 & 38 \\
\hline Selective relative frequency $\mathrm{p}$ & 0.206 & 0.452 & 0.238 & 0.393 & 0.717 \\
\hline $\mathrm{H} 0=$ & 0.6 & 0.6 & 0.6 & 0.7 & 0.7 \\
\hline $\mathrm{H} 1>$ & 0.6 & 0.6 & 0.6 & 0.7 & 0.7 \\
\hline Test criterion & -9.020 & -4.469 & -8.292 & -9.924 & 0.270 \\
\hline Critical range for $\alpha=0.05$ & 1.645 & 1.645 & 1.645 & 1.645 & 1.645 \\
\hline Evaluation & $\begin{array}{l}\text { We reject } \\
\text { the } \\
\text { hypothesis } \\
\text { H1 }\end{array}$ & $\begin{array}{l}\text { We reject } \\
\text { the } \\
\text { hypothesis } \\
\text { H1 }\end{array}$ & $\begin{array}{l}\text { We reject } \\
\text { the } \\
\text { hypothesis } \\
\text { H1 }\end{array}$ & $\begin{array}{l}\text { We reject } \\
\text { the } \\
\text { hypothesis } \\
\text { H1 }\end{array}$ & $\begin{array}{l}\text { We reject } \\
\text { the } \\
\text { hypothesis } \\
\text { H1 }\end{array}$ \\
\hline
\end{tabular}

\begin{tabular}{|l|l|l|l|l|l|l|}
\hline Tested hypothesis & 1 & 2 & 3 & 4 & 5 & 6 \\
\hline Total respondents & 219 & 53 & 166 & 93 & 26 & 219 \\
\hline Total matching & 114 & 2 & 52 & 39 & 15 & 124 \\
\hline Selective relative frequency p & 0.521 & 0.038 & 0.313 & 0.419 & 0.577 & 0.566 \\
\hline H0= & 0.6 & 0.6 & 0.7 & 0.6 & 0.6 & 0.7 \\
\hline H1> & 0.6 & 0.6 & 0.7 & 0.6 & 0.6 & 0.7 \\
\hline Test criterion & -2.400 & -8.356 & -10.874 & -3.556 & -0.240 & -4.321 \\
\hline Critical range for $\alpha=0.05$ & 1.645 & 1.645 & 1.645 & 1.645 & 1.645 & 1.645 \\
\hline & $\begin{array}{l}\text { We reject } \\
\text { the } \\
\text { hypothesis } \\
\text { H1 reject }\end{array}$ & $\begin{array}{l}\text { We reject } \\
\text { the } \\
\text { hypothesis } \\
\text { the } \\
\text { hypothesis } \\
\text { Evaluation }\end{array}$ & $\begin{array}{l}\text { We rect } \\
\text { the We reject } \\
\text { hypothesis } \\
\text { H1 }\end{array}$ & $\begin{array}{l}\text { We } \\
\text { the } \\
\text { hypothesis } \\
\text { the } \\
\text { hypothesis } \\
\text { H1 }\end{array}$ \\
\hline
\end{tabular}

Summarizing the results, it can be said that all the hypotheses, which were formulated at the beginning of our research, were rejected. Our assumptions are thus not confirmed.

\section{CONCLUSIONS}

Work has many meanings for people. For absolute majority of people, work is a source of earnings that are exchanged for goods to meet their needs. Work is also a means of self-realization.

Just like work also its evaluation in both tangible and intangible forms is important for people. The results of our empirical investigation revealed that workers in the Ostrava Region prefer tangible appreciation of their work $(52.05 \%)$. The results also showed that employees are fond of new forms of employee benefits such as sick days and free days. 
For employers or managers it is valuable, if they know which forms of intangible employee benefits are preferred by their employees. Managers can better regulate employee benefits, namely towards their optimization. Providing benefits not preferred by employees will not bring employers such an effect, as those they are interested in. In addition the economics of intangible employee benefits must be noted as they are associated with costs, or expenses. Optimization efforts are therefore clearly justified and necessary. We believe that the results of our empirical investigation can be a guide in creating benefit programs of companies and institutions.

\section{REFERENCES}

[1] BĚLOHLÁVEK, F. Organizační chováni : jak se každý den chovají spolupracovníci, nadř́zení, podřizení, obchodni partneři či zákazníci. 1st edition. Olomouc : Rubico, 1996. 343 p. ISBN 80-8583909-1.

[2] Dopady finančni krize na podnikání v České republice [online]. [cit. 23/02/2011]. Available from WWW:

<http://www.cnb.cz/miranda2/export/sites/www.cnb.cz/cs/verejnost/pro_media/konference_projevy/vysto upeni_projevy/download/rezabek_20090317_caki.pdf>.

[3] DRUCKER, P, F. To nejdůležitějši z Drucera v jednom svazku. 1st edition. Prague: Management Press, 2002. 300 p. ISBN 80-7261-066-X.

[4] HINDLS, R; HRONOVÁ, S; SEGER, J. Statistika pro ekonomy. 1st edition. Prague: Professional Publishing, 2002. 415 p. ISBN 80-86419-26-6.

[5] HRON, J.; MACÁK, T. Organizační chování, teoretické podklady. Prague: ČZU PEF, 2008. ISBN 97880-213-1589-1.

[6] JANEČEK, V; HYNEK, J. Motivační systém jako faktor zvyšování efektivnosti podniku. [online]. [cit.2011-01-31]. Available from WWW: <http://www.faqs.org/periodicals/201001/1975382781.html>.

[7] Komunikovat a motivovat [online]. [cit. 24/08/2010]. Available from WWW: <http://hn.ihned.cz/c135915690-komunikovat-a-motivovat>.

[8] Motivace zaměstnanců - jak na to [online]. [cit. 08/09/2010]. Available from WWW: < <http://www.mineralfit.cz/prace-a-kariera-clanek/motivace-zamestnancu-jak-na-to-55/>.

[9] Odměňování v době krize [online]. [cit. 23/02/2011]. Available from WWW:

< http://www.pwc.com/cz/cs/clanky-2009/odmenovani-v-dobe-krize.jhtml>.

[10] Třetina firem sáhla svým zaměstnancưm na benefity [online]. [cit. 24/08/2010]. Available from WWW: <http://podnikani.idnes.cz/tretina-firem-sahla-svym-zamestnancum-na-benefity-fsl/zamestnani.asp?c=A100707_1413109_zamestnani_hru>.

[11] Zaměstnanecké benefity za časů krize [online]. [cit. 04/11/2010]. Available from WWW: <http://cfoworld.cz/ostatni/zamestnanecke-benefity-za-casu-krize-178>.

[12] ZADRAŽILOVÁ, D; KHELEROVÁ, V. Management obchodni firmy. 1st edition. Prague: 2008 [1994]. 304 p. ISBN 80-85623-72-2.

\section{RESUMÉ}

Správná aplikace zaměstnaneckých benefitů ve firmách je v současnosti nezbytným předpokladem pro udržení pozic na stávajících trzích.

V tomto článku bylo na základě dotazníkového šetření provedeného na Ostravsku prokázáno, které motivační faktory jsou dnes ze strany zaměstnanců preferovány nejvíce a o které naopak zájem klesá. $Z$ vyhodnocení vyplynulo, že bez ohledu na různé demografické charakteristiky respondentů má pro ně aktuálně největší význam jistota zaměstnání, možnost získání 13. a 14. platu a dny dovolené navíc.

Pravidelné sledování a vyhodnocování preferencí zaměstnanců má velký význam pro vytváření účinné motivační strategie podniků a tím vede ke spokojenosti samotných zaměstnanců, což je nezbytným předpokladem pro konkurenceschopnost. 